\title{
Thermally Stable Fluorogenic Zn(II) Sensor Based on a Bis(benzimidazole)pyridine-Linked Phenyl-Silsesquioxane Polymer
}

\author{
Chamika U. Lenora, Nai-hsuan Hu, and Joseph C. Furgal*
}

Cite This: ACS Omega 2020, 5, 33017-33027

Read Online

ABSTRACT: A 2,6-bis(2-benzimidazolyl) pyridine-linked silsesquioxane-based semi-branched polymer was synthesized, and its photophysical and metal-sensing properties have been investigated. The polymer is thermally stable up to $285{ }^{\circ} \mathrm{C}$ and emits blue in both solid and solution state. The emission of the polymer is sensitive to $\mathrm{pH}$ and is gradually decreased and quenched upon protonation of the linkers. The initial emission color is recoverable upon deprotonation with triethylamine. The polymer also shows unique spectroscopic properties in both absorption and emission upon long-term UV irradiation, with red-shifted absorption and emission not present in a simple blended system of phenylsilsesquioxane and linker, suggesting that a long-lived energy

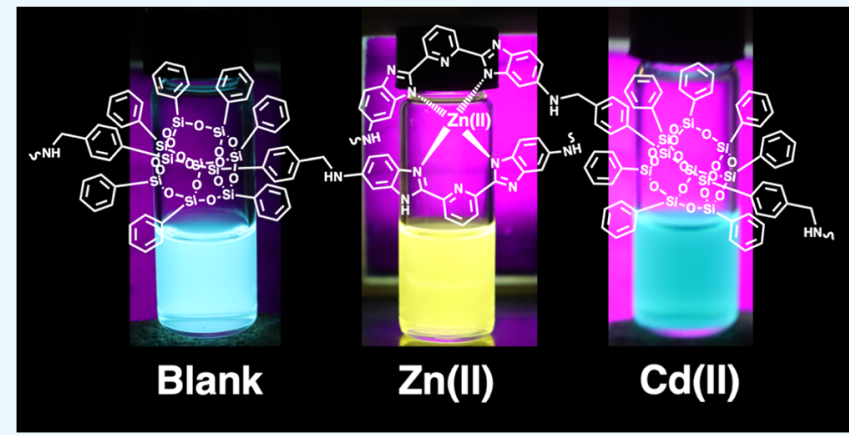
transfer or charge separated state is present. In addition, the polymer acts as a fluorescence shift sensor for $\mathrm{Zn}$ (II) ions, with red shifts observed from 464 to $528 \mathrm{~nm}$, and reversible binding by the introduction of a competitive ligand such as tetrahydrofuran. The ion sensing mechanism can differentiate $\mathrm{Zn}$ (II) from $\mathrm{Cd}$ (II) by fluorescence color shifts, which is unique because they are in the same group of the periodic table and possess similar chemical properties. Finally, the polymer system embedded in a paper strip acts as a fluorescent chemosensor for $\mathrm{Zn}$ (II) ions in solution, showing its potential as a solid phase ion extractor.

\section{INTRODUCTION}

Zinc is the most abundant element in the human body after iron and is an essential element necessary for plants and microorganisms. ${ }^{1} \mathrm{Zn}$ plays a vital role in numerous biological processes including metabolism of DNA and RNA, gene expression, and signal transduction. ${ }^{2-4}$ Furthermore, $\mathrm{Zn}$ imbalance in the human body is associated with a number of diseases including Alzheimer's, epilepsy, ischemic stroke, and certain cancers. ${ }^{5-13}$ Because $\mathrm{Zn}$ (II) is spectroscopically silent because of its $\mathrm{d}^{10}$ electron configuration, sensitive and noninvasive fluorescence sensing becomes the most promising technique for $\mathrm{Zn}$ analysis and imaging. Various fluorophorebased chemosensors such as quinoline, ${ }^{14-19}$ dansyl, ${ }^{20-22}$ coumarin, $^{23-27}$ and fluorescein ${ }^{28}$ have been developed to sense $\mathrm{Zn}$ (II). Even though there are many sensors developed for $\mathrm{Zn}(\mathrm{II})$, a need still remains for highly selective, nontoxic sensors. Furthermore, most of the $\mathrm{Zn}$ (II) sensors reported so far are not able to differentiate $\mathrm{Zn}$ (II) from $\mathrm{Cd}(\mathrm{II})$ because these two are in the same group of the periodic table and have similar chemical properties. In addition, current $\mathrm{Zn}$ (II) sensors show low thermal and photochemical stability, poor mechanical properties, and photo degradation upon UV exposure which are disadvantages concerning their technological applicability. One solution to improve the mechanical and optical properties of $\mathrm{Zn}$ (II) sensors is to introduce a stable rigid matrix such as silica-based hybrid materials.
Polyhedral oligomeric silsesquioxanes (POSS) are cage-like molecules with rigid inorganic silica core surrounded by easily modifiable organic groups. These POSS derivatives are known to improve thermal stability, brightness, and quantum efficiency in electroluminescence materials and photostability of photonic systems. ${ }^{29-33}$ POSS-based materials have been recently studied as sensors for cations, ${ }^{34-39}$ anions, ${ }^{40,41}$ and other analytes, ${ }^{42-44}$ and are often combined with metals to form metallo-supramolecular structures. ${ }^{45,46}$ For example, Ervithayasuporn et al. recently developed a single cage $T_{10}$ POSS rhodamine-functionalized fluorescence sensor for selective and noncompetitive $\mathrm{Hg}$ (II) binding in the presence of a number of competing cations. ${ }^{36}$ They have also shown POSS systems as anion sensors. ${ }^{40,41}$ Aprile et al. also looked at $\mathrm{T}_{8}$ cages with monosubstitution terpyridine ligands for $\mathrm{Eu}^{3+}$ binding and fluorescence on/off effects, with isomerization being able to tune the absorption and emission spectra. ${ }^{35}$ They have also made a series of nanostructured materials out of similar octa-terpyridyl-functionalized POSS to build up Zn(II)-

Received: September 7, 2020

Accepted: December 4, 2020

Published: December 16, 2020 
Scheme 1. Synthesis of Bis(benzimidazole)pyridine-Functionalized Silsesquioxane-Based Polymer $(\text { P1 })^{a}$
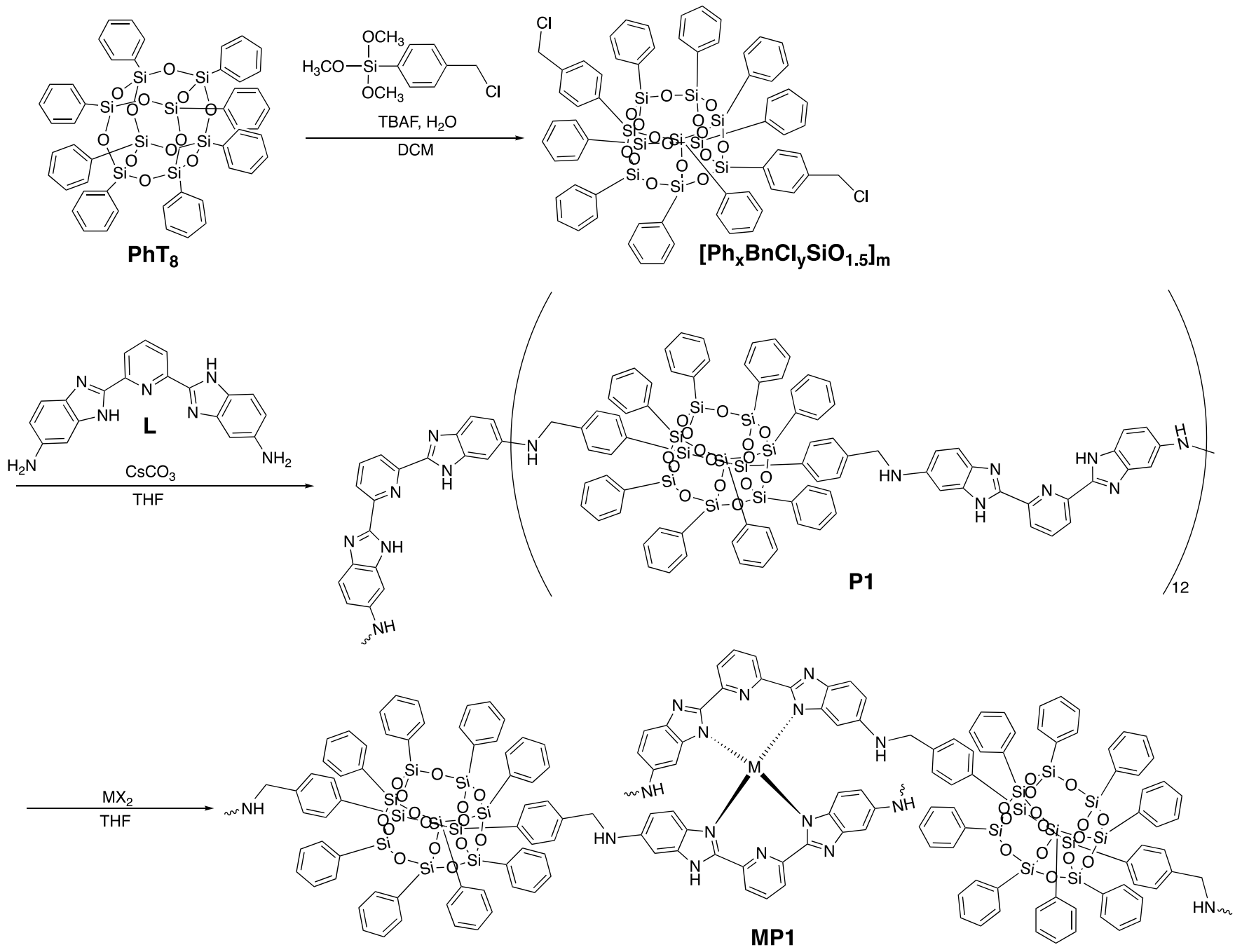

${ }^{a} \mathrm{MP1}$ is a model structure based on four coordinate binding with metal ions after metalation with $\mathrm{MX}_{2} ; x=5-11, y=1-5$, and $m=10$ or 12 .

and $\mathrm{Fe}(\mathrm{II})$-linked metallo-supramolecules that have reversible photo-thermal sol-gel transitions. ${ }^{47}$ Porous network POSS systems are often very effective sensing systems because of their solid-state interactions with ions, which allows for noninvasive sensing. ${ }^{34,43,48}$ Liu and Liu described a selective POSS network with tetraphenylethene links, which is capable of selective $\mathrm{Fe}$ (III) capture in the presence of other ions. ${ }^{34}$ More similar designs to our system are based on double decker silsesquioxanes with terpyridine functionality on each side of the cage for making metallo-supramolecular systems using $\mathrm{Ru}$ (II) for polymers ${ }^{45}$ or $\mathrm{Pt}(\mathrm{II})$ for making nano-cores. ${ }^{46,49}$ Thus far, selective $\mathrm{Zn}$ (II) fluorescence sensors based on silsesquioxane systems have not yet been established.

In this study, phenyl-substituted POSS was chosen as the starting material and was functionalized with ( $p$ chloromethyl)phenyltrimethoxysilane to react with $2,2^{\prime}$-(pyridine-2,6-diyl)bis(3H-benzo[d]imidazole-5-amine), which could sense $\mathrm{Zn}$ (II). 2,6-Bis(2-benzimidazolyl)pyridine contains three types of electron-donating nitrogens, including two imidazolic nitrogen atoms and one pyridine nitrogen which makes it a good tridentate ligand for transition metals ${ }^{50-53}$ and provides excellent fluorogenic character. ${ }^{54-56}$ This ligand has been studied as a fluorescence sensor for recognizing zinc and as a colorimetric sensor to differentiate $\mathrm{Fe}(\mathrm{II})$ from $\mathrm{Fe}$ (III). ${ }^{55,57}$

Herein, we report thermally stable fluorescence sensors based on bis(benzimidazole)pyridine-functionalized silsesquioxane polymer which has the ability to differentiate $\mathrm{Zn}$ (II) from Cd(II) ions. The polymer emits blue in both solid and solution state and is soluble in most organic solvents and insoluble in water. The emission is $\mathrm{pH}$ sensitive with gradual reduction in fluorescence and eventually quenched upon protonation. When the polymer is exposed to different metal ions in solution, the fluorescence can be quenched, spectralshifted, or unchanged. Furthermore, the polymer emits yellow in the presence of $\mathrm{Zn}(\mathrm{II})$ and greenish blue with $\mathrm{Cd}(\mathrm{II})$, indicating the ability to differentiate $\mathrm{Zn}$ (II) from $\mathrm{Cd}(\mathrm{II})$. In addition, the polymer is stable up to $285{ }^{\circ} \mathrm{C}$ while the linker itself is only stable up to $92{ }^{\circ} \mathrm{C}$.

\section{RESULTS AND DISCUSSION}

Polymer Synthesis. The investigations in this manuscript are based on a 2,2'-(pyridine-2,6-diyl)bis ( $3 H$-benzo[d]imidazole-5-amine)-functionalized phenylsilsesquioxane polymer (P1), which was synthesized according to the synthetic route shown in Scheme 1. 2,2'-(Pyridine-2,6-diyl)bis $(3 \mathrm{H}$ - 
benzo[d]imidazole-5-amine), (L) was synthesized following a reported procedure. ${ }^{59}$ From Scheme 1, PhT8 was treated with tetra- $n$-butylammonium fluoride (TBAF), water, and ( $p$ chloromethyl)phenyltrimethoxysilane in dichloromethane (DCM) to obtain (chloromethylphenyl) $2-3$-substituted $\mathrm{PhT}_{10 / 12}$-mixed cages $\left(\left[\mathrm{Ph}_{x} \mathrm{BnCl}_{y} \mathrm{SiO}_{1.5}\right]_{m}\right.$, where $x=5-11, y$ $=1-5$, and $m=10$ or 12 ). The obtained cages are a $1.2: 1$ mixture of $T_{10}$ and $T_{12}$ silsesquioxane structures (only $T_{10}$ shown in Scheme 1 for simplicity) and contain a statistical range of chloromethylphenyl groups from 1 to 5, with an average functionality of $\sim 2.5$ units per cage as per MALDIToF analysis (Figure S2), and was also verified by nuclear magnetic resonance (NMR) (Figures S3-S5). This cage set was reacted with $2,2^{\prime}$-(pyridine-2,6-diyl)bis $(3 H$-benzo[d]imidazole-5-amine) and $\mathrm{CsCO}_{3}$ in tetrahydrofuran (THF) to obtain the polymer. Polymer P1 was characterized by NMR, gel permeation chromatography (GPC), Fourier-transform infrared spectroscopy (FTIR), thermal gravimetric analysis (TGA), and spectroscopic methods, with spectra shown in the text and Supporting Information. Proton NMR shows extensive peak broadening over the starting cage structures and the incorporated linkers, consistent with forming a polymeric structure (Figures S7 and S8). Defining features show that the cross-linker is indeed incorporated into the structure, with further evidence given by ${ }^{13} \mathrm{C}$ NMR (Figures S9 and S10). ${ }^{29} \mathrm{Si}$ NMR (Figure S11) of P1 shows peaks at -80 and $-81 \mathrm{ppm}$, indicating the presence of mixed cages in the polymer. GPC analysis shows a molecular weight distribution, PDI of 1.4 and on average 12 repeat units (Figure S12); however, this is only an estimation because the semi-branched structures stemming from the POSS cages have multiple distributed reaction sites and there are hydrodynamic volume differences between POSS systems and polystyrene standards. FTIR analysis shows that the silsesquioxane cage structure is maintained throughout the synthesis process (Figure S13), which is evidenced by the presence of strong $\nu \mathrm{Si}-\mathrm{O}$ bands at 1020 and $1090 \mathrm{~cm}^{-1}$. The presence of two IR bands for $\mathrm{Si}-\mathrm{O}$ stretching further indicates the presence of mixed cages in P1. The characteristic ligand vibration bands for $\mathrm{C}=\mathrm{C}$ and $\mathrm{C}=\mathrm{N}$ appeared at 1600 and $1590 \mathrm{~cm}^{-1}$, respectively. The presence of strong vibration band at $1430 \mathrm{~cm}^{-1}$ represents the $\mathrm{C}-\mathrm{N}$ stretching modes of pyridine rings. The aromatic $\mathrm{C}-\mathrm{H}$ stretching band appears at $\sim 3050 \mathrm{~cm}^{-1}$. The amine $\mathrm{N}-\mathrm{H}$ stretching band appears at $3550 \mathrm{~cm}^{-1}$. TGA analysis (Figure 1) revealed that the polymer is stable up to $285{ }^{\circ} \mathrm{C}\left(T_{\mathrm{d} 5 \%}\right)$ and gives a ceramic yield (CY) of 39\% (experimental) versus $37 \%$

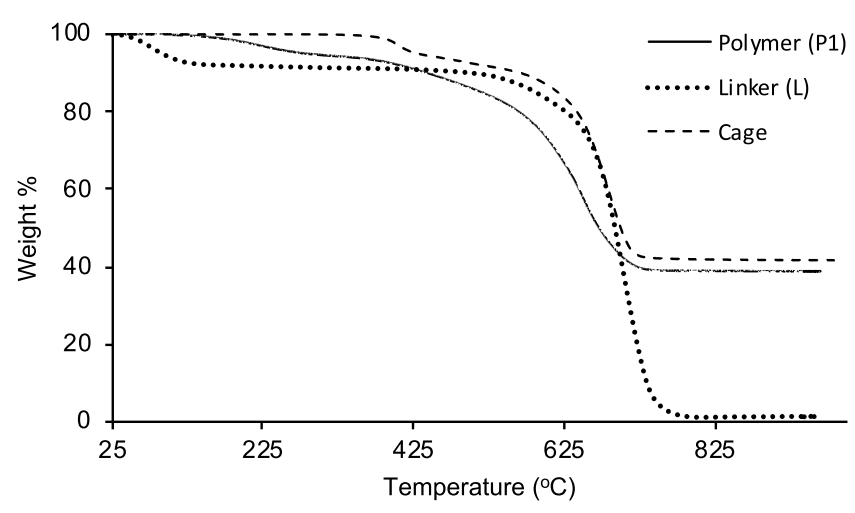

Figure 1. TGA of the linker (......), cage (-----), and polymer (-) (air/10 ${ }^{\circ} \mathrm{C} \min ^{-1}$ ). (theory, assuming $\mathrm{T}_{12}$ as a base structure of the mixed system and one linker). Comparable polymeric systems have thermal stabilities of $300-550{ }^{\circ} \mathrm{C} .{ }^{60}$ The error between theoretical and experimental CYs can be attributed to additional organic components from polymer end capping with linkers as well as variations in the cage size. The linker itself is only stable up to $92{ }^{\circ} \mathrm{C}\left(T_{\mathrm{d} 5 \%}\right)$.

Photophysical Characterization [Nonmetalated Polymer (P1)]. To probe the photophysical properties of polymer (P1), absorption, emission, and quantum yields (QYs) were obtained. The UV-visible spectrum in THF (Figure 2)

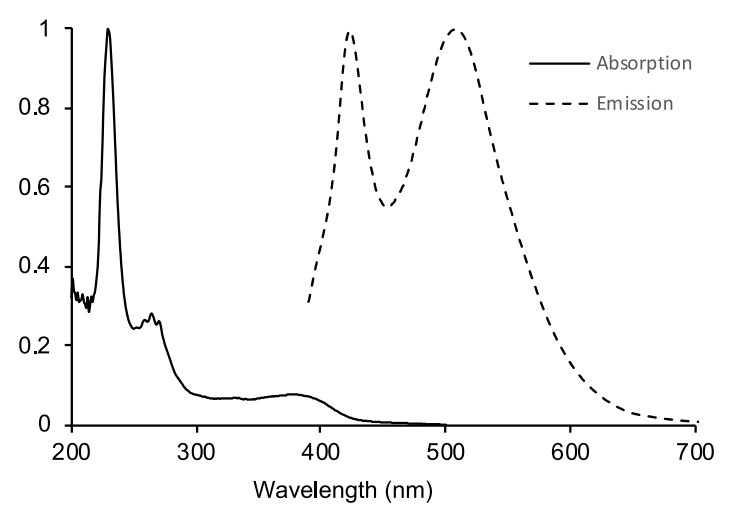

Figure 2. Normalized absorption (--) and emission (---) of polymer $(0.025 \mathrm{mM})$ in THF. Excitation wavelength is $380 \mathrm{~nm}$.

showed three absorption peaks centered at $230 \mathrm{~nm}(\varepsilon=6.98 \times$ $\left.10^{5} \mathrm{M}^{-1} \mathrm{~cm}^{-1}\right), 264 \mathrm{~nm}\left(\varepsilon=3.31 \times 10^{4} \mathrm{M}^{-1} \mathrm{~cm}^{-1}\right)$, and 380 $\mathrm{nm}\left(\varepsilon=1.03 \times 10^{4} \mathrm{M}^{-1} \mathrm{~cm}^{-1}\right)$. The absorption band at 380 $\mathrm{nm}$ was assigned to $\pi$ to $\pi^{*}$ transition in linker $(\mathbf{L})$, while the band at $264 \mathrm{~nm}$ was assigned to $\pi$ to $\pi^{*}$ transition in phenyl groups in the silsesquioxane cages $\left[\mathrm{Ph}_{x} \mathrm{Bn}_{y} \mathrm{SiO}_{1.5}\right]_{m}$. The polymer emits blue in THF and a dilute solution of polymer in THF $(0.1 \mu \mathrm{M})$ emits at $424 \mathrm{~nm}$ when excited at $380 \mathrm{~nm}$, and the emission is red shifted with increasing concentration (Figure S14). At a $0.05 \mathrm{mM}$ concentration, we observed that there are two peaks in the emission spectrum, one is at $425 \mathrm{~nm}$ and the other one is at $510 \mathrm{~nm}$. We suspected that this low energy emission band arises because of aggregation or excimer formation with cage phenyls. ${ }^{60,61}$ To support our proposed explanation for aggregation or excimer formation, we obtained concentration-dependent emission of the polymer in THF. At high concentration, two peak emissions were observed and they gradually become a single peak that blue shifted with decreasing concentration. The emission intensity also increases with increasing concentration, with $0.05 \mathrm{mM}$ concentration at nearly $3 \times$ higher intensity than that of $0.1 \mu \mathrm{M}$, suggesting an aggregation-induced fluorescence enhancement. In the aggregated state, single molecular rotations are locked because of several intermolecular interactions between polymer molecules, which strengthen the $\pi$-conjugation and cause red shifts in the emission spectra. This observation suggests that the low energy emission band is most likely attributed to aggregation of polymers in solution through hydrogen bonding interactions between the $\mathrm{N}-\mathrm{H}$ moieties. Similar effects are also observed for the linker (L), which on its own excited at $380 \mathrm{~nm}$ (Figure S15) and showed little overall electronic contribution from the cage $\left(\left[\mathrm{Ph}_{x} \mathrm{Bn}_{y} \mathrm{SiO}_{1.5}\right]_{m}\right.$ component, which has no emission when excited at $380 \mathrm{~nm}$. When P1 and $\mathbf{L}$ were excited at 280 $\mathrm{nm}$ instead (phenyl band), single peak, but weak emission 
spectra are obtained with maxima at $\sim 450 \mathrm{~nm}$, which is also observed for DCM (Table 1). We were also concerned about

Table 1. Absorption, Emission Maxima, Stokes Shift, and QY in Different Solvents ${ }^{a}$

\begin{tabular}{|c|c|c|c|c|}
\hline solvent & $\lambda_{\mathrm{Abs}}(\mathrm{nm})$ & $\begin{array}{c}\lambda_{\text {Emission }} \\
(\mathrm{nm})\end{array}$ & $\begin{array}{l}\text { Stokes shift } \\
\quad\left(\mathrm{cm}^{-1}\right)\end{array}$ & $\begin{array}{c}\text { PLQY } \\
(\%)\end{array}$ \\
\hline toluene & 284 & 447 & 12,717 & 31 \\
\hline benzene & $\begin{array}{c}227,265 \\
380\end{array}$ & 424,466 & 14,883 & 33 \\
\hline tetrahydrofuran & $\begin{array}{c}228,265 \\
380\end{array}$ & 416,513 & 24,367 & 32 \\
\hline ethyl acetate & 265,326 & 453 & 15,661 & 26 \\
\hline chloroform & $\begin{array}{l}236,267 \\
332\end{array}$ & 452 & 19,873 & 24 \\
\hline DCM & $\begin{array}{l}226,265 \\
380\end{array}$ & 450 & 21,831 & 25 \\
\hline acetone & 218,326 & 473 & 24,729 & 11 \\
\hline dimethylformamide & 265 & 490 & 17,328 & 10 \\
\hline
\end{tabular}

the influence of water on the fluorescence spectra of P1 because THF chromatography grade is not usually dry. However, regardless of using dry or standard THF, the spectra (Figure S16) are very similar. This suggests that the aggregation effect is not because of water but the relative closeness of the molecules. When water is deliberately added to P1 solution ( $0.05 \mathrm{mM}, \mathrm{THF})$ in $2 \mu \mathrm{L}$ aliquots up to $10 \mu \mathrm{L}$, the two fluorescence bands begin to coalesce into one central band. This suggests that water is breaking up the internal and/ or intramolecular hydrogen bonding interactions between the L units (Figure S17). This makes fluorescence appear more similar to that obtained in less concentrated solutions shown in Figure S14.

Effect of Solvation. To study the influence of solvent polarity on emission, we obtained emission in different solvents. Figure S18 shows an image of P1 fluorescence in various solvents. The polymer (P1) is soluble in many organic solvents except alcohols such as methanol and ethanol. Table 1 lists the absorption and emission maxima as well as Stokes shift and fluorescence quantum efficiencies of $\mathbf{P 1}$ in different solvents. P1 emits blue in most of the organic solvents except in acetone and dimethylformamide (Figure S19), which have a very quenched green fluorescence. To have a quantitative picture, we obtained the fluorescence quantum efficiency of P1 in different organic solvents with varying polarities using an integrating sphere system (Table 1). The QY is also comparatively low in acetone and DMF which is likely due to lower solubilities induced by higher polarity suggests that the emission color changes and quenching observed for DMF and acetone are more likely attributed to extensive low solubility-induced aggregation, as opposed to strong water interactions even though they appear quite soluble.

Significant solvatochromism is observed in the absorption spectra for each of these solvent systems (Figure S20). For example, the maximum absorption in solvents such as toluene and benzene which offer significant possibilities for $\pi-\pi$ interactions seems to show considerable mixing of absorption bands and results in an intermediate absorption between the ligand $(\mathrm{L}, 380 \mathrm{~nm})$ and cage phenyl bands $(\sim 260 \mathrm{~nm})$. However, even after subtracting the background, the significant absorption for these two solvents is most likely from the solvents themselves, which is a typical issue for having absorption in a similar region. ${ }^{62}$ Because of these solvents' minimal emissions, the $380 \mathrm{~nm}$ excited emission maxima are coming from $\mathbf{L}$ alone. Polar solvents also show interesting effects in absorption. Acetone shows a strongly split two band absorption system (218 and $320 \mathrm{~nm}$ ), suggesting that groundstate aggregation effects are likely strong for this system, causing large isolation between the bands. ${ }^{83,64}$ These sorts of solvatochromic effects are not uncommon in amine-rich systems. ${ }^{64}$ When intermediate polarity solvents are used (THF, DCM, ethyl acetate, and chloroform), the absorption is relatively consistent and shows strong phenyl absorption bands in the $265 \mathrm{~nm}$ region. The differences here are the relative strengths of the absorption bands, which can change relative to solubilization effects of the cage components.

Influence of Acidity/Basicity. Polymer P1 has many bridge/ligand sites that can be influenced by acid/base changes in their local environment. While our initial focus was to look at metal binding as discussed later, we found interesting fluorescence changes upon adjusting the solution acidity and basicity. The emission is weakened/quenched at high acidities. In acidic conditions, the pyridine unit in the linker can be protonated, leading to a significant quenching of the luminescence. The luminescence can return by adding a base such as triethylamine (Figure 3); however, just like in the

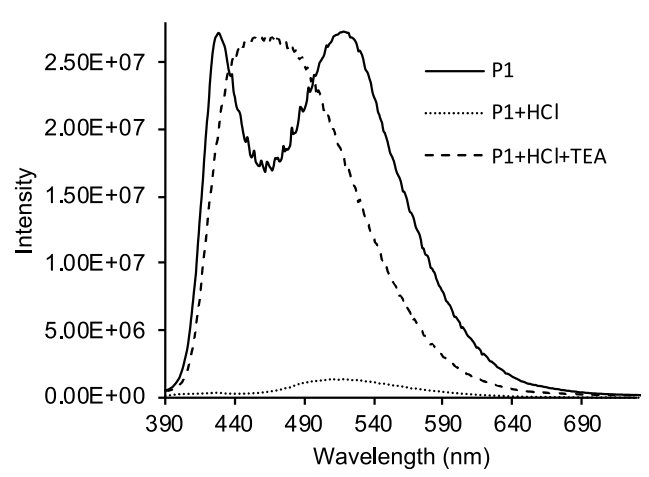

Figure 3. Emission spectra of P1 (-, $0.02 \mathrm{mM})$ in THF ( $4 \mathrm{~mL}), \mathbf{P 1}$ with $20 \mathrm{mM}$ TFA $(\cdots)$, and fluorescence turned back on (----) when $150 \mu \mathrm{L}$ of triethylamine was added. Excitation wavelength is $380 \mathrm{~nm}$.

water experiments (Figure S17), the emission bands coalesce. This is likely due to the breaking of internal hydrogen bonding interactions. In this case, it is semi-reversible because it does not return to its original state but a hydrogen bondingdisrupted state of the same emission color. To test the influence of acids on the emission of the polymer, we performed a titration experiment with trifluoroacetic acid (TFA) with a total concentration from 1 to $10 \mathrm{mM}$. In the titration experiment, an increasing amount of TFA was added to a solution of polymer in THF and changes in fluorescence intensity were measured (Figure S21). The emission intensity of P1 $(0.02 \mathrm{mM})$ was decreased by $9 \%$ when TFA was first added, and the intensity was further decreased and significantly quenched with a total TFA concentration of $20 \mathrm{mM}$. When $150 \mu \mathrm{L}$ of triethylamine are added, emission intensity returns to its original value (Figure 3). Protonating the ligand can quench fluorescence through low solubility-induced aggregation or other nonradiative decay pathways, which adds significant cationic potential to $\mathbf{P 1}$. 


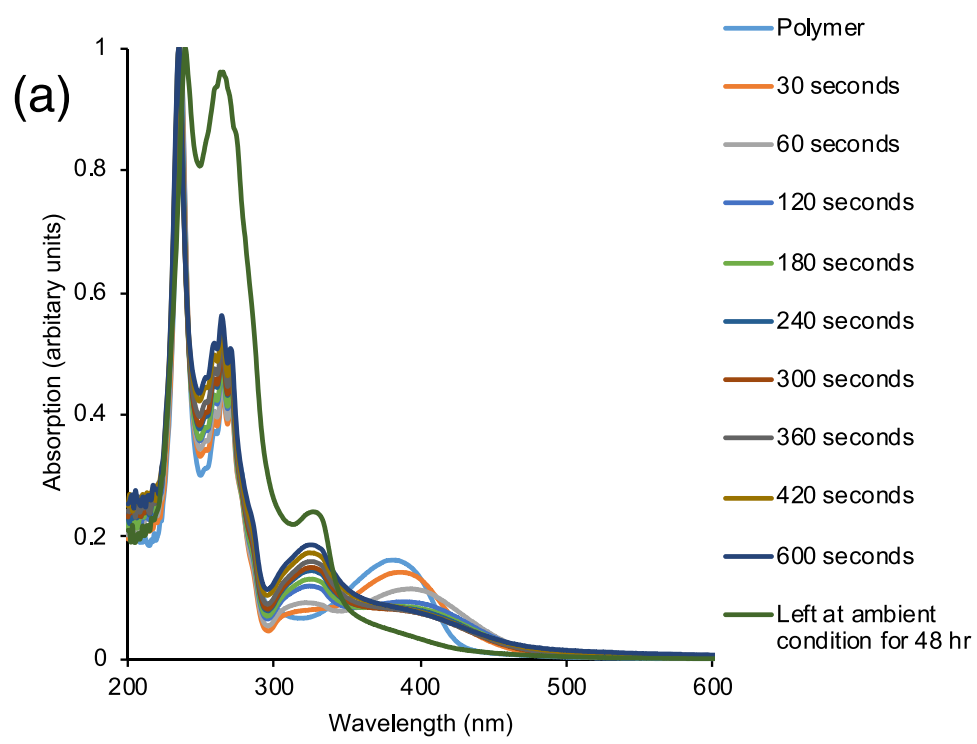

(b)

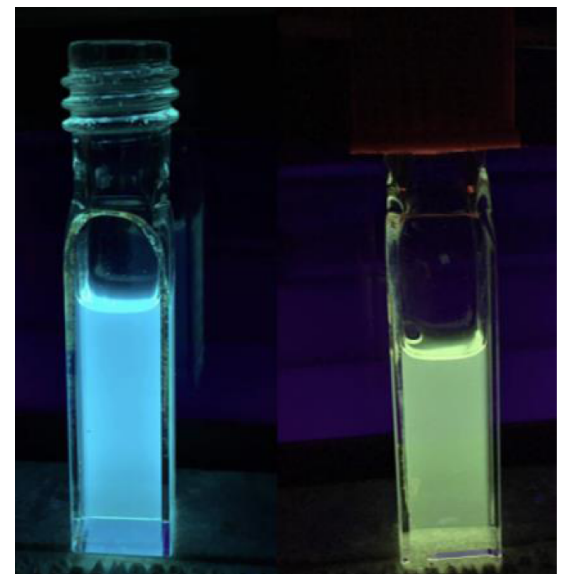

Figure 4. (a) Absorption spectra of P1 $(0.05 \mathrm{mM})$ over $600 \mathrm{~s}$ of $25 \mathrm{~mW} / \mathrm{cm}^{2}$ of UV irradiation and partial recovery after $48 \mathrm{~h}$; (b) photoluminescence of the polymer P1 (left) before UV irradiation and (right) after $600 \mathrm{~s}$ UV irradiation in THF.

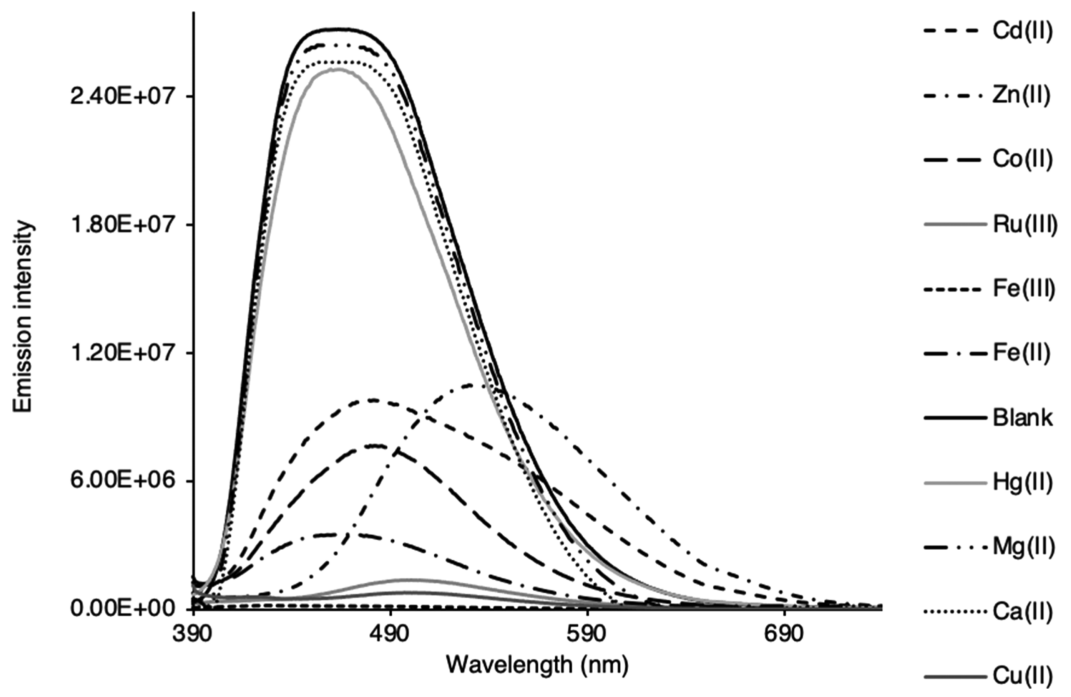

Figure 5. Emission spectra of polymer in DCM in the presence of various cations. [P1] $=0.008 \mathrm{mM}$. Excitation wavelength is $380 \mathrm{~nm}$.

Polymer Stability/UV Irradiation Effects. To use polymer systems for applications such as recyclable sensors, their stability to many external stimuli such as light and heat must be determined. The polymer P1 shows excellent thermal stability, as given above $\left(285^{\circ} \mathrm{C}\right)$. To test polymer stability to UV irradiation, a sample of $\mathbf{P 1}$ in DCM was irradiated with 25 $\mathrm{mW} / \mathrm{cm}^{2}$ from a UV reactor and absorption was measured at regular time intervals from 30 to $600 \mathrm{~s}$ (Figure 4). Irradiation with UV light for $30 \mathrm{~s}$ caused the absorption peak at $380 \mathrm{~nm}$ to shift to $388 \mathrm{~nm}$ with an intensity decrease of $13 \%$, and a new absorption band appears at $322 \mathrm{~nm}$. Further irradiation slightly shifted the absorption to longer wavelengths and after $10 \mathrm{~min}$, the absorption at $380 \mathrm{~nm}$ was diminished by $50 \%$. We attempted to follow these changes by both FTIR (Figure S22) and ${ }^{1} \mathrm{H}$ NMR; however, clear changes in the structure could not be observed at $10 \mathrm{~min}$ of irradiation or after $48 \mathrm{~h}$ recovery. We also noticed that the emission color of P1 changed from blue to yellow upon irradiation (Figure 4b), but when the 10 min UV irradiated polymer was left at ambient conditions for
$48 \mathrm{~h}$, polymer emission was restored to its original color, albeit at slightly diminished intensity. The loss of the ligand (L) absorption band at $380 \mathrm{~nm}$ in Figure 4 suggests that there is irreparable damage to the ligand by UV irradiation and that this quenched emission comes from the small amount of ligand L that was not damaged.

To try and understand whether this absorption and emission change was truly a polymer phenomenon, we set up a series of control experiments (Figure S23). In addition to looking at the P1 irradiation, we looked at the ligand (L) individually, $\left[\mathrm{Ph}_{x} \mathrm{BnCl}_{y} \mathrm{SiO}_{1.5}\right]_{m}$ alone, and also as a blend of $\mathbf{L}$ with the $\mathrm{T}_{10} \mathrm{Ph}$ cage. ${ }^{58}$ Note that we did not use the $\left[\mathrm{Ph}_{x} \mathrm{BnCl}_{y} \mathrm{SiO}_{1.5}\right]_{m}$ cage because we observed substantial UV-induced substitution processes resulting in analogous P1 type polymer formation. We observe very different phenomenon depending on whether the system is a blend or the polymer. With the polymer, extensions in the absorption wavelength are observed after continued UV irradiation as discussed above, whereas in the mixed system, it behaves similarly to what is found for the 
ligand and cage on their own, without the extension of absorption out to $500 \mathrm{~nm}$. By emission (Figure S24), we see a red shift and quenching of emission for the polymer from 506 to $530 \mathrm{~nm}$ after $10 \mathrm{~min}$ exposure to UV, while the ligand + $\mathrm{T}_{10} \mathrm{Ph}$ shows no shift in emission and only a slight decrease in emission intensity. This shows no energy transfer occurred in the blend and suggests that the change induced by the polymer is unique and different from that of the ligand and cage. Therefore, the effect seems to be localized in the polymer system and there does not appear to be an intramolecular photo-induced electron transfer (PET) process occurring. We could be introducing a intramolecular PET in the polymer system or a UV-induced excited/charge separated state that is long lived and appears to give rise to potential pseudo $\pi$ conjugation between the linkers and/or silsesquioxane cage phenyls. ${ }^{65,66}$ The excited state-induced orientation changes likely give more favorable $\pi$ to $\pi$ interactions. Overall, the polymer and ligand systems show relatively low UV stability, but the effects of UV irradiation are something we will explore further in the future.

Polymer Metalation: Fluorogenic Zn(II) Sensing Studies. To avoid the interference from aggregation, we performed all sensing experiments below the aggregation concentration of the polymer $(<0.1 \mathrm{mM})$. The blue emission of P1 can be ascribed to intraligand $\pi$ to $\pi^{*}$ transitions. ${ }^{50}$ To utilize the metal sensing ability of P1, we measured the change in fluorescence in the presence of various metal ions including $\mathrm{Zn}(\mathrm{II}), \mathrm{Cd}(\mathrm{II}), \mathrm{Fe}(\mathrm{II}), \mathrm{Fe}(\mathrm{III}), \mathrm{Cu}(\mathrm{II}), \mathrm{Co}(\mathrm{II}), \mathrm{Ru}(\mathrm{III})$, $\mathrm{Hg}$ (II), $\mathrm{Mg}$ (II), and $\mathrm{Ca}(\mathrm{II})$ to make metal-bound polymer MP1 (Figure 5). We carried out the sensory experiment in DCM because metal complexes are not stable in THF because of competitive ligation (Figure S25). The addition of $\mathrm{Zn}$ (II) $(0.1 \mathrm{mM})$ into a solution of polymer $(0.008 \mathrm{mM})$ in DCM resulted in a $64 \mathrm{~nm}$ red shift in the emission spectra with a significant quenching of the maximum fluorescence intensity. However, Cd(II) which is in same group of the periodic table as $\mathrm{Zn}$ (II) and exhibits similar chemical properties only showed a $20 \mathrm{~nm}$ bathochromic shift. $\mathrm{Zn}$ (II) caused a polymer fluorescence shift from blue to yellow, while $\mathrm{Cd}(\mathrm{II})$ gave a shift from blue to green, indicating that the polymer can differentiate $\mathrm{Zn}(\mathrm{II})$ from $\mathrm{Cd}(\mathrm{II})$. This is likely due to the different coordination preferences of the two ions. Because of steric hindrance from the size of the phenyl cages and its close interactions with the ligand system, Co(II) is less able to bind in its preferred six coordinate structural motif, meaning that the system, likely favors tetrahedral binding, which is preferred for $\mathrm{Zn}(\mathrm{II}) .^{51}$ The coordinative behavior of the $\mathrm{Cd}(\mathrm{II})$ ion resembles that of $\mathrm{Hg}(\mathrm{II})$, and to a lesser extent $\mathrm{Zn}(\mathrm{II}) .^{54}$

Other ions mostly showed fluorescence quenching but little shift in the emission spectrum. The fluorescence of the polymer is reduced upon interacting with $\mathrm{Co}$ (II) by $70 \%$ and with $\mathrm{Fe}(\mathrm{II})$ by $86 \%$ and completely quenched by $\mathrm{Fe}(\mathrm{III})$, $\mathrm{Cu}(\mathrm{II})$, and $\mathrm{Ru}(\mathrm{III})$. The spectral pattern and the fluorescence intensity did not change with $\mathrm{Mg}$ (II), $\mathrm{Ca}(\mathrm{II})$, and $\mathrm{Hg}(\mathrm{II})$, which indicate that these ions do not bind with the polymer (Figure 5).

Because of the strong change in fluorescence of $\mathrm{Zn}$ (II) binding, we focused on experiments to better understand this phenomenon. To quantify the amount of $\mathrm{Zn}$ (II) bound in the MP1 complex, a titration experiment was carried out using fluorescence emission (Figures 6 and S26). In this experiment, the polymer concentration was kept constant at $0.16 \mathrm{mM}$ and increasing amounts of $\mathrm{Zn}$ (II) was added (0.001-0.2 mM).

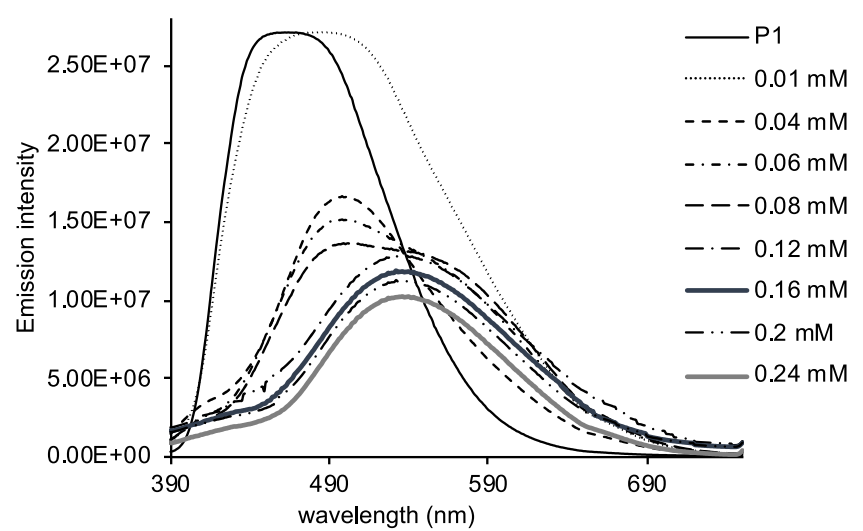

Figure 6. Change in emission of polymer P1 (concentration with 12 repeating units $0.16 \mathrm{mM}$ ) upon adding increasing amounts of $\mathrm{Zn}$ (II).

The polymer in DCM emits at $464 \mathrm{~nm}$, and the emission gradually shifts to $528 \mathrm{~nm}$ and quenches slightly upon adding increasing amounts of $\mathrm{Zn}$ (II). A plot between the change in emission peak wavelength versus $\mathrm{Zn}$ (II) concentration (Figure 7) shows approximately 1:2 ( $\mathrm{Zn} /$ ligand) binding between each

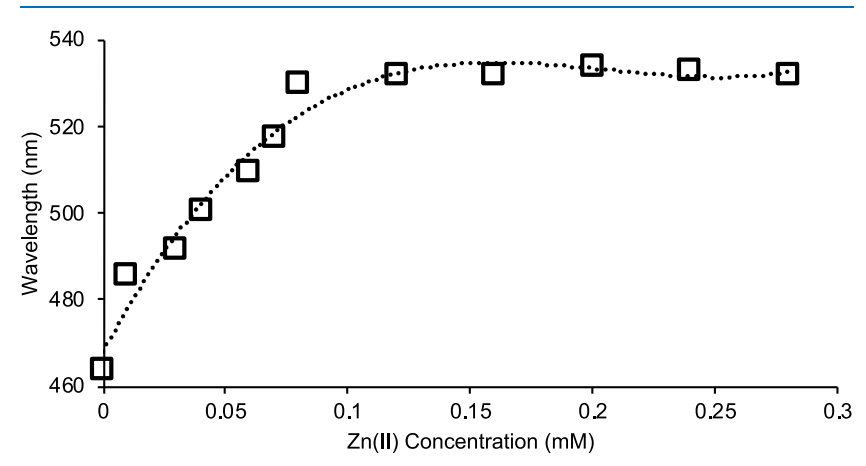

Figure 7. Change in the emission peak wavelength vs the concentration of $\mathrm{Zn}$ (II) in DCM. P1 concentration with 12 repeating units $=0.16 \mathrm{mM}$.

of the polymer repeating units and $\mathrm{Zn}$ (II) before plateauing. This suggests that either multiple polymers are binding together, or multiple units on the same polymer are interacting to form complexes. To determine the $K_{\mathrm{a}}$ value of binding, we used a modified Benesi-Hildebrand equation for the determination of $\mathrm{Zn}(\mathrm{II})$ binding constant from fluorescence quenching studies (Figure S27). We used the methods of Das et al. ${ }^{67}$ and $\mathrm{Xu}$ et al. ${ }^{68}$ to determine binding. $K_{\mathrm{a}}$ was estimated to be $3.6 \times 10^{2} \mathrm{M}^{-0.5}$ based on $1: 2 \mathrm{Zn}$ (II) to ligand binding. The minimum detectible concentration was calculated using $3 \sigma / m$, where $\sigma$ is the standard deviation of ten repeated measurements of $\mathbf{P 1}$ alone. The minimum detection limit is calculated to be $0.03 \mathrm{mM}$ for $\mathrm{Zn}(\mathrm{II})$. Note that no emission from P1 alone remains, which is further evidence of communication throughout the polymer system, with any unbound ligands being invisible. Multipolymer complexation was also verified by GPC (Figures S13 and S28).

In addition to the $\mathrm{Zn}$ (II) binding study, we also explored the removal of bound $\mathrm{Zn}$ (II) from MP1. Because we had found through preliminary experiments that THF inhibited $\mathrm{Zn}$ (II) binding, it was thought that it could also be used to demetalate the polymer and restore blue emission. In this experiment (Figures 8 and S27), to a $1 \mathrm{mM}$ solution of P1 in DCM was added $0.05 \mathrm{~mL}$ of $1 \mathrm{mM} \mathrm{Zn}$ (II) in THF to achieve a slightly 


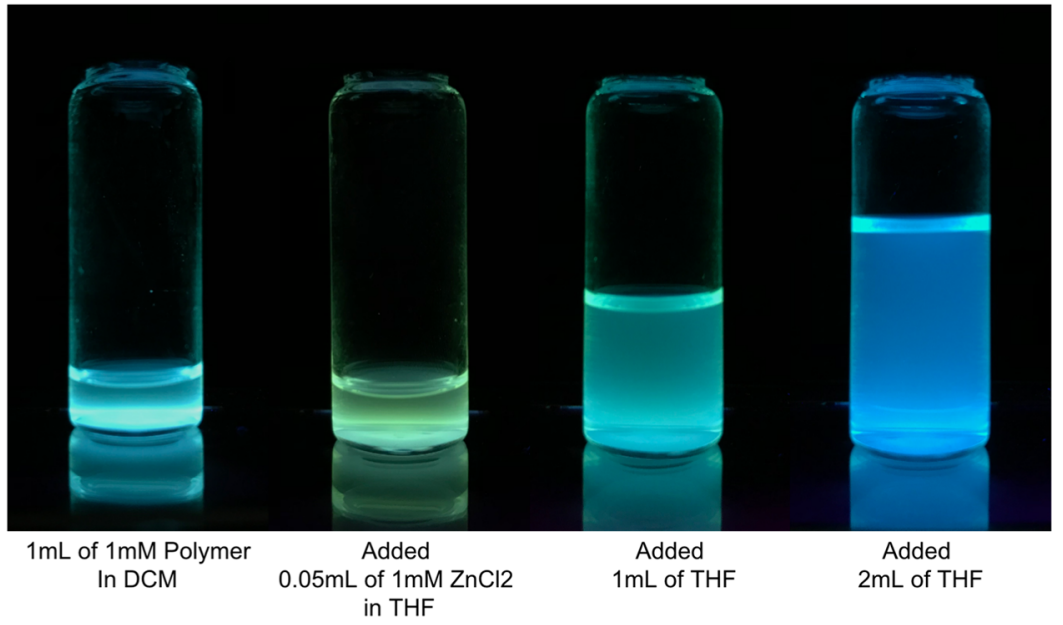

Figure 8. $\mathbf{P 1}$ in DCM at $1 \mathrm{mM}$ to $\mathrm{MP1}$ with $\mathrm{Zn}$ added $(0.05 \mathrm{~mL}$ of $1 \mathrm{mM} \mathrm{ZnCl}$ ) back to P1 by addition of THF.

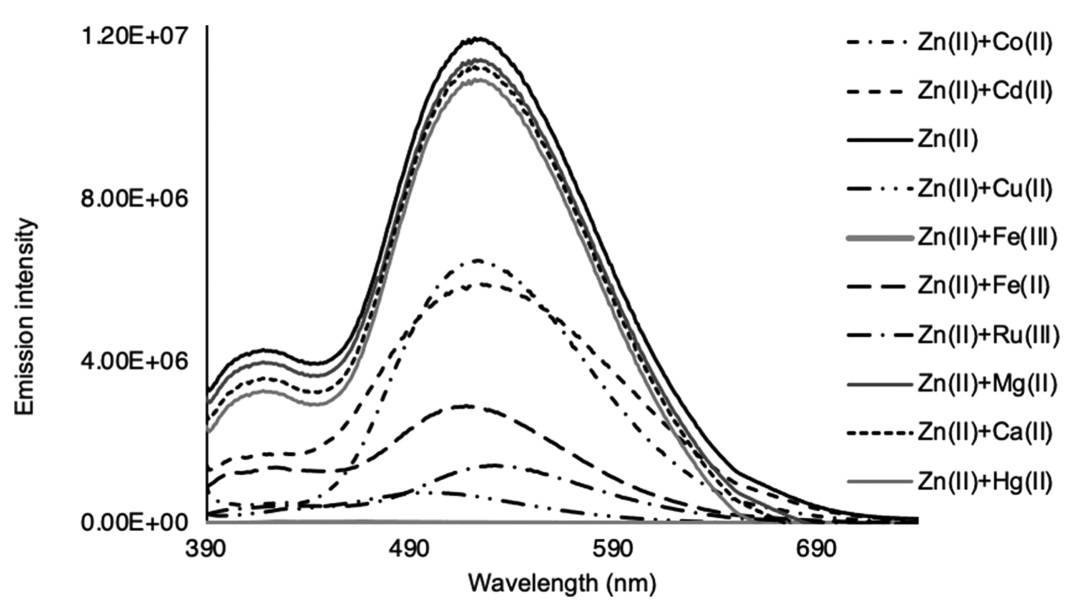

Figure 9. Emission spectra of $\mathrm{Zn}(\mathrm{II})-\mathrm{MP1}$ in the presence of various metal cations. Excitation wavelength is $380 \mathrm{~nm}$ in DCM.

yellow-green emission. THF is used for solubility reasons. THF is then added in $1 \mathrm{~mL}$ aliquots to disrupt the $\mathrm{Zn}$ (II) binding to restore blue emission of the unbound P1. This shows that we can remove $\mathrm{Zn}$ (II) from the polymer as needed using a simple solvent-induced method. Emission spectra are given in Figure S27, showing the shifts in color upon metalation and demetalation.

The selectivity of the polymer for $\mathrm{Zn}$ (II) over other cations was studied by measuring the change in fluorescence intensity of MP1 with $\mathrm{Zn}(\mathrm{II})$ in the presence of other metal ions in a 1:1 metal ion mol ratio in excess based on P1 concentration (Figure 9). The emission peak for $\mathrm{Zn}$ (II)/polymer is still observed at $528 \mathrm{~nm}$ with very little intensity change in the presence of $\mathrm{Mg}(\mathrm{II}), \mathrm{Ca}(\mathrm{II})$, and $\mathrm{Hg}$ (II). These data show that $\mathrm{Mg}$ (II), $\mathrm{Ca}(\mathrm{II})$, and $\mathrm{Hg}$ (II) ions do not compete with $\mathrm{Zn}$ (II) for binding with P1. Co(II) and Cd(II) quench the emission of the $\mathrm{Zn}(\mathrm{II})-\mathrm{MP1}$ complex by $\sim 50 \%$, indicating that these ions have either considerable interference with the affinity of P1 to $\mathrm{Zn}$ (II) ions, or they offer a sort of colligative property similar to adding additional $\mathrm{Zn}(\mathrm{II})$ to the polymer system where quenching is also observed. However, the position of maximum emission and peak shape remains similar to the $\mathrm{Zn}$ (II) system (Figure S28). Integration of the bound $\mathrm{Zn}$ (II) + $\mathrm{Cd}$ (II) peak compared to $\mathrm{Zn}$ (II) alone also confirms the $50 \%$ quenching with equal binding affinity of each metal. Surprisingly, Cd(II) becomes invisible spectroscopically and the fluorescence color maintains a yellow appearance, which would not be observed by $\mathrm{Cd}(\mathrm{II})$ alone. It is likely that $\mathrm{Cd}(\mathrm{II})$ and $\mathrm{Co}$ (II) funnel energy to quench nonradiatively. Therefore, we can still distinguish the presence of $\mathrm{Zn}$ (II) from that of $\mathrm{Cd}(\mathrm{II})$ and $\mathrm{Co}(\mathrm{II})$. Attempts to deconvolute the spectra of the two sets of ions from each other were not possible because of the near overlap of the $\mathrm{Zn}(\mathrm{II})+\mathrm{Cd}(\mathrm{II})$ spectrum with $\mathrm{Zn}$ (II) alone (Figure S28). In the presence of $\mathrm{Fe}(\mathrm{II})$, emission is quenched by $75 \%$, and $\mathrm{Fe}(\mathrm{III}), \mathrm{Cu}(\mathrm{II})$, and $\mathrm{Ru}(\mathrm{III})$ completely quenched the emission. This is expected based on the significant quenching observed in the single ion test of Figure 5 and indicates significant competitive binding of these ions with $\mathrm{Zn}$ (II) to form MP1 structures.

One of the interesting uses of this type of polymer system is as an extraction device for dissolved cations. To test the ability of the polymer to extract $\mathrm{Zn}$ (II) from water, P1 (1.5 mg) was dissolved in minimum amounts of DCM and added to an aqueous solution of $\mathrm{Zn}$ (II) ( $1 \mathrm{mM}$ ). The emission color of the polymer was instantaneously changed from blue to yellow, indicating that P1 is able to extract $\mathrm{Zn}$ (II) efficiently from aqueous solution. Then, the polymer was separated from water and added to THF. In THF, the emission color of the $\mathrm{Zn}(\mathrm{II})-$ MP1 complex was changed from yellow to blue, indicating that $\mathrm{Zn}$ (II)-polymer complex was dissociated. This result indicates the ability of the polymer to extract metals from an aqueous solution and then release them effectively (Figure 10). 

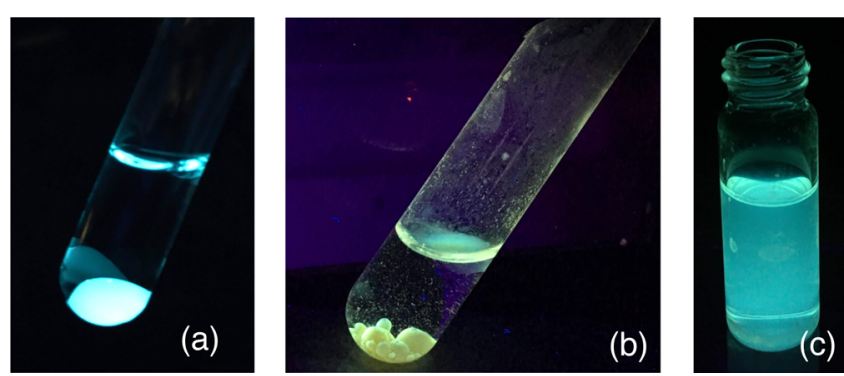

Figure 10. (a) Emission of polymer in the water/DCM mixture (polymer was dissolved in minimum amounts of DCM and added to water). (b) Emission of polymer when P1 was added to aqueous solution of $\mathrm{Zn}(\mathrm{II})$. (c) Emission color of extracted $\mathrm{Zn}(\mathrm{II})-\mathrm{MP1}$ in THF.

Last, we tested the feasibility of $\mathbf{P 1}$ to sense $\mathrm{Zn}$ (II) in the solid state as a sensor (Figure 11). For this, we first soaked a

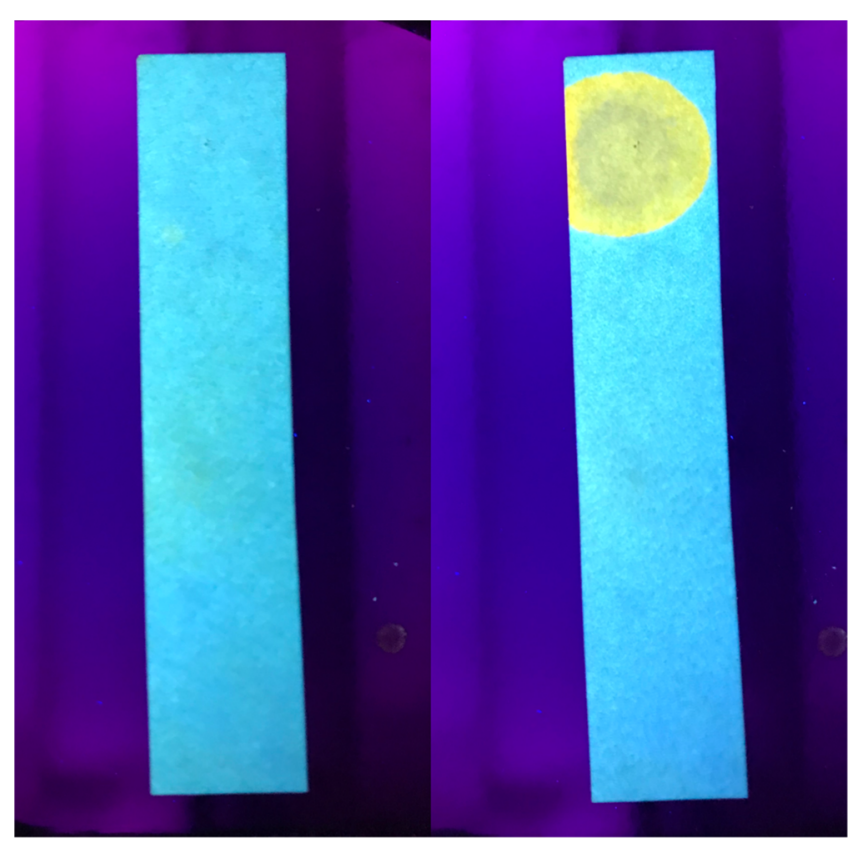

Figure 11. Photoluminescence image of the polymer on the filter paper (blue) and change in fluorescence upon adding 1 drop of $\mathrm{Zn}$ (II) in water solution (yellow).

filter paper in a solution of P1 (THF, $10 \mathrm{mM}$ ) to allow the polymer to enter the fiber structure. The filter paper was then dried to complete the solid phase $\mathrm{Zn}$ (II) test strip. Analysis of the test strip efficacy toward $\mathrm{Zn}(\mathrm{II})$ was conducted by placing a drop of $\mathrm{Zn}$ (II) in THF and water solution (4 mM). The emission color of the polymer was instantaneously changed from blue to yellow, indicating that P1 is still able to sense $\mathrm{Zn}$ (II) in the solid state as well.

\section{CONCLUSIONS}

In summary, a $2,2^{\prime}$-(pyridine-2,6-diyl)bis $(3 H$-benzo[d]imidazole-5-amine)-linked silsesquioxane based polymer is synthesized, and its photophysical properties and fluorogenic $\mathrm{Zn}$ (II) sensing ability were measured. The polymer emits blue in both solid and solution state with significant solvatochromic effects in different solvents. The emission is sensitive to $\mathrm{pH}$ of the solution and is quenched upon adding an acid. The quenched fluorescence can return with neutralization by a base. The polymer shows unique absorption and emission effects such as red-shifted absorptions and emission upon UV irradiation, which are semireversible and polymer-dependent. We observe that the ligand is not strongly stable to UV irradiation, and the actual chemistry that is taking place will be investigated more fully in the future. The emission color of the polymer was changed from blue to yellow upon interacting with $\mathrm{Zn}$ (II) ions with the introduction of a $64 \mathrm{~nm}$ spectral shift, dissimilar to any other metal ions tested. The polymer is able to extract $\mathrm{Zn}$ (II) ions from water solutions in the solid state and reversibly unbind by the addition of THF as a competitive ligand. This demonstrates the polymer's potential as a fluorescence-based $\mathrm{Zn}$ (II) sensor in both solution and solid state.

\section{EXPERIMENTAL METHODS}

Materials. Commercially available chemicals were used without further purification unless otherwise noted in the text. ( $p$-Chloromethyl)phenyltrimethoxysilane was purchased from Gelest, Inc. 2,6-Bis(2-benzimidazolyl)pyridine was purchased from TCI Organics. Octaphenylsilsesquioxane (OPS) $\left(\mathrm{T}_{8} \mathrm{Ph}\right)$ was a gift from Mayaterials Inc. Decaphenylsilsesquioxane $\left(\mathrm{T}_{10} \mathrm{Ph}\right)$ was synthesized using a published procedure. ${ }^{58}$ TBAF (1.0 M in THF) was obtained from Acros Organics. 2,2' (Pyridine-2,6-diyl)bis (3H-benzo[d]imidazole-5-amine) (L) was synthesized following a reported procedure (Figure S1). ${ }^{59}$

Synthesis of Chloromethylphenyl-Substituted Phenyl Silsesquioxane Cage. Chloromethylphenyl-substituted phenyl silsesquioxane cage $\left(\left[\mathrm{Ph}_{x} \mathrm{BnCl}_{y} \mathrm{SiO}_{1.5}\right]_{m}\right.$, where $x=5-$ $11, y=1-5$, and $m=10$, or 12 : OPS $(2.4 \mathrm{~g}$, $2.3 \mathrm{mmol})$ was placed in a $1 \mathrm{~L}$ round-bottom flask, and DCM $(400 \mathrm{~mL})$ was added. To the suspension of OPS in DCM, TBAF $(0.25 \mathrm{~mL}$, $0.25 \mathrm{mmol}, 1.0 \mathrm{M}$ ), $0.3 \mathrm{~mL}$ of water, and 4-(chloromethyl)phenyltrimethoxysilane $(1.7 \mathrm{~g}, 6.9 \mathrm{mmol})$ were added, and the reaction mixture was stirred for $72 \mathrm{~h}$ at room temperature. To quench the reaction, $\mathrm{CaCl}_{2}(0.15 \mathrm{~g}, 1.3 \mathrm{mmol})$ was added and stirred overnight. The solid was filtered off, and the filtrate was concentrated under reduced pressure to obtain a white solid. The solid was dissolved in a minimum amount of THF and precipitated into $150 \mathrm{~mL}$ of $\mathrm{MeOH}$. The precipitate was collected and dried in vacuo to obtain a white solid ( $2.2 \mathrm{~g}, 92 \%$ with relevant to the total initial mass of OPS). ${ }^{1} \mathrm{H}$ NMR (500 $\mathrm{MHz}_{\mathrm{CDCl}}$ ): $\delta 4.66\left(\mathrm{t}, \mathrm{Ar}-\mathrm{CH}_{2}-\mathrm{Cl}\right), 6.7-8.0(\mathrm{~m}, \mathrm{Ar}-\mathrm{H})$; ${ }^{13} \mathrm{C} \mathrm{NMR}\left(500 \mathrm{MHz}, \mathrm{CDCl}_{3}\right): \delta 139.83,134.27,130.00$, 128.08 (Ar-C), $46.02\left(\mathrm{CH}_{2}\right.$ bridge $){ }^{29} \mathrm{Si} \mathrm{NMR}(59.6 \mathrm{MHz}$, $\mathrm{CDCl}_{3}$ with TMS reference): $\delta-78.00,-79.28,-81.11$; FTIR: $695\left(\nu_{\mathrm{C}-\mathrm{Cl}}\right), 729\left(\nu_{\mathrm{Si}-\mathrm{C}}\right), 1100\left(\nu_{\mathrm{Si}-\mathrm{O}}\right), 1430\left(\nu_{\mathrm{C}=\mathrm{C},} \mathrm{Ar}\right.$ ring), $1590\left(\nu_{\mathrm{C}=\mathrm{C}}\right.$ Ar ring $), 2850-3070\left(\nu_{\mathrm{C}-\mathrm{H}}\right)$. MALDITOF: $m / z\left(\mathrm{Ag}^{+}\right.$adducts $)=\mathrm{T}_{10}: 1448\left(\mathrm{Ph}_{9} \mathrm{ClBn}_{2}\right), 1497$ $\left(\mathrm{Ph}_{8} \mathrm{ClBn}_{3}\right), 1546\left(\mathrm{Ph}_{7} \mathrm{ClBn}_{3}\right), 1594\left(\mathrm{Ph}_{6} \mathrm{ClBn}_{4}\right), \mathrm{T}_{12}: 1755$ $\left(\mathrm{Ph}_{10} \mathrm{ClBn}_{2}\right), 1804\left(\mathrm{Ph}_{9} \mathrm{ClBn}_{3}\right), 1854\left(\mathrm{Ph}_{8} \mathrm{ClBn}_{4}\right), 1900$ $\left(\mathrm{Ph}_{7} \mathrm{ClBn}_{5}\right)$. TGA (air, $1000{ }^{\circ} \mathrm{C}$ ): found, $42 \%$; calcd, $39 \%$. $T_{\mathrm{d} 5 \%}: 431{ }^{\circ} \mathrm{C}$ (Figures $\mathrm{S} 2-\mathrm{S} 6$ ).

Synthesis of Polymer P1. To a dry $100 \mathrm{~mL}$ flask was added $2.0 \mathrm{~g}$ of chloromethylphenyl-substituted phenyl cage, $0.08 \mathrm{~g}$ of $2,2^{\prime}$-(pyridine-2,6-diyl)bis $(3 \mathrm{H}$-benzo[d]imidazole-5amine), $0.15 \mathrm{~g}$ of $\mathrm{CsCO}_{3}$, and $50 \mathrm{~mL}$ of THF. The resulted solution was stirred at $65{ }^{\circ} \mathrm{C}$ for $72 \mathrm{~h}$. The solvent was removed from the reaction mixture, the resulted solid was dissolved in THF, and the cross-linked polymer was precipitated. The precipitate was filtered off, and the filtrate was dried under vacuum to obtain an orange color solid. The resulted solid was redissolved in minimum amounts of THF 
and was precipitated into water. The product was filtered off and dried in vacuo to obtain light orange powder. ${ }^{1} \mathrm{H}$ NMR $\left(500 \mathrm{MHz}, \mathrm{THF}-d_{8}\right): \delta 4.5\left(\mathrm{br}, \mathrm{CH}_{2}\right), 6.2-7.8$ (br, Ar-H, aliph. NH), 10.90 (ArN-H). ${ }^{13} \mathrm{C}$ NMR (500 MHz, THF- $\left.d_{8}\right): \delta$ 140.81, 135.25, 131.41, 128.72, 126.38 (Ar-C), $46.71\left(\mathrm{CH}_{2}\right.$ bridge). ${ }^{29} \mathrm{Si} \mathrm{NMR}\left(59.6 \mathrm{MHz}, \mathrm{CDCl}_{3}\right.$ with TMS reference): $\delta$ -80 (b), -81 (b). FTIR: $695\left(\nu_{\mathrm{C}-\mathrm{Cl}}\right), 730\left(\nu_{\mathrm{Si}-\mathrm{C}}\right), 1020,1090$ $\left(\nu_{\mathrm{Si}-\mathrm{O}}\right), 1430\left(\nu_{\mathrm{C}=\mathrm{C}}, \mathrm{Ar}\right.$ ring $), 1590\left(\nu_{\mathrm{C}=\mathrm{C}}, \mathrm{Ar}\right.$ ring $), 1600$, 2850-3080 $\left(\nu_{\mathrm{C}-\mathrm{H}}\right.$ and $\left.\nu_{\mathrm{N}-\mathrm{H}}\right)$. TGA (air, $\left.1000{ }^{\circ} \mathrm{C}\right)$ : found, $39 \%$; calcd, $36 \%$. $T_{\mathrm{d} 5 \%}: 285{ }^{\circ} \mathrm{C}$. GPC: $M_{\mathrm{n}}=17 \mathrm{kDa}, M_{\mathrm{w}}=20$ $\mathrm{kDa}, \mathrm{PDI}=1.4$ (Figures $\mathrm{S} 7-\mathrm{S} 13$ ).

Analytical Methods. Fourier-Transform Infrared Spectroscopy (FTIR). Spectra were obtained on a Thermo Scientific Nicolet iS5 Fourier transform infrared spectrometer. The attenuated total reflection method was used. Without further sample preparation, solid samples were placed on a $\mathrm{ZnSe}$ crystal and scanned from 4000 to $400 \mathrm{~cm}^{-1}$ for 16 scans with $0.121 \mathrm{~cm}^{-1}$ data spacing.

Thermal Gravimetric Analysis. Thermal stabilities and CYs of samples in air were measured on a TA Instruments TGA-50. Samples of $20-25 \mathrm{mg}$ were placed into an alumina pan and heated from 25 to $950{ }^{\circ} \mathrm{C}$ at a rate of $10{ }^{\circ} \mathrm{C} / \mathrm{min}$ with $60 \mathrm{~mL} /$ min air-flow.

Gel Permeation Chromatography. GPC analysis was performed on a Shimadzu LC-10 system (LC Solutions Software) equipped with a set of Waters Styragel columns (HR $0.5,1,3$, and 4) with a Shimadzu RID-10 RI detector and SPD-10a UV detector with THF as the eluent at a $1 \mathrm{~mL} / \mathrm{min}$ flow rate. This system was calibrated using a set of eight polystyrene standards, with toluene used as an internal reference.

Nuclear Magnetic Resonance. ${ }^{1} \mathrm{H}$ NMR and ${ }^{13} \mathrm{C}$ NMR were obtained using a $500 \mathrm{MHz}$ Bruker Avance Spectrometer. Chemical shifts are reported relative to residual solvent signals $\left(\mathrm{CDCl}_{3},{ }^{1} \mathrm{H}: \delta 7.26 ;{ }^{13} \mathrm{C}: \delta\right.$ 77.36; THF- $d_{8},{ }^{1} \mathrm{H}: \delta 1.73,3.58$; $\left.{ }^{13} \mathrm{C}: \delta 25.37,67.47\right) .{ }^{1} \mathrm{H}$ NMR data are assumed to be of first order, and the multiplicity is reported as " $\mathrm{s}$ " = singlet and " $\mathrm{m}$ " $=$ multiplet, and so forth.

UV-Vis Spectrometry. UV-vis measurements were recorded on a Shimadzu UV-2600 spectrometer with the resolution of $1.0 \mathrm{~nm}$ with $1 \mathrm{~s}$ integration time. All measurements were performed using quartz cuvette with a path length of $0.5 \mathrm{~cm}$ at room temperature. Concentrations were on the order of $\left(10^{-6}\right.$ to $\left.10^{-7} \mathrm{M}\right)$. Molar extinction coefficients $\left(\varepsilon \mathrm{M}^{-1} \mathrm{~cm}^{-1}\right)$ were determined by plotting a standard curve with concentrations ranging from $10^{-5}$ to $10^{-6}$ M.

QY Measurements. The absolute QYs were measured using a Hamamatsu Quantaurus absolute QY spectrometer QYC11347 with integrating sphere. All optical measurements were performed using a quartz cuvette with a path length of 1 $\mathrm{cm}$ at room temperature.

Fluorescence Spectroscopy (PL). The fluorescence spectra were measured on a HORIBA Fluorolog 3 photo-luminescence spectrometer with a $1 \mathrm{~cm}$ quartz cuvette at room temperature. Samples were prepared as outlined below.

Sample Preparation for PL/QY Metalation Studies. Stock solution of polymer (P1) in DCM ( $5 \mathrm{mM})$ was diluted to prepare $0.008 \mathrm{mM}$ solution, and an aliquot of different metal ions was added to make the final metal ion concentration 1 mM. $\mathrm{ZnCl}_{2}, \mathrm{CoCl}_{2}, \mathrm{Cd}\left(\mathrm{NO}_{3}\right)_{2}, \mathrm{FeCl}_{2}, \mathrm{FeCl}_{3}, \mathrm{Cu}\left(\mathrm{NO}_{3}\right)_{2}$, and $\mathrm{RuCl}_{3}$ are soluble in THF. Those metals were dissolved in THF and metalated with polymer in DCM to form metalated polymer MP1. Polymer samples for fluorogenic sensing experiments were prepared by dissolving $2 \mathrm{mg}$ of polymer in $2 \mathrm{~mL}$ of DCM. Then, solvent was evaporated and the metalated polymer was redissolved in DCM and filtered through a $0.2 \mu \mathrm{m}$ filter before taking measurements. $\mathrm{MgCl}_{2}$, $\mathrm{CaCl}_{2}$, and $\mathrm{Hg}\left(\mathrm{NO}_{3}\right)_{2}$ were soluble in water. Those metals were dissolved in water and metalated with polymer in DCM. Then, solvent was removed and redissolved in DCM and any solid formed was filtered with a $0.2 \mu \mathrm{m}$ filter.

To prepare samples for the metal selectivity study, polymer was dissolved in minimum amounts of DCM and first metalated with $\mathrm{Zn}$ (II), then equal amounts of other competitive ions were added as dissolved in THF or water and mixed together. All solvents were then removed, and the resulted solid was redissolved in DCM again. Any precipitate formed was filtered with a $0.2 \mu \mathrm{m}$ filter, and the filtrate was used for the analysis.

\section{ASSOCIATED CONTENT}

\section{Supporting Information}

The Supporting Information is available free of charge at https://pubs.acs.org/doi/10.1021/acsomega.0c04366.

NMR, FTIR, TGA, UV/vis, and fluorescence data (PDF)

\section{AUTHOR INFORMATION}

\section{Corresponding Author}

Joseph C. Furgal - Department of Chemistry and Center for Photochemical Sciences, Bowling Green State University, Bowling Green, Ohio 43403, United States; (o orcid.org/ 0000-0002-7040-0793; Email: furgalj@bgsu.edu

\section{Authors}

Chamika U. Lenora - Department of Chemistry and Center for Photochemical Sciences, Bowling Green State University, Bowling Green, Ohio 43403, United States

Nai-hsuan $\mathrm{Hu}$ - Department of Chemistry and Center for Photochemical Sciences, Bowling Green State University, Bowling Green, Ohio 43403, United States

Complete contact information is available at:

https://pubs.acs.org/10.1021/acsomega.0c04366

\section{Notes}

The authors declare no competing financial interest.

\section{ACKNOWLEDGMENTS}

The authors thank Bowling Green State University for Startup Funding.

\section{REFERENCES}

(1) Mertz, W. The Essential Trace Elements. Science 1981, 213, $1332-1338$

(2) Maret, W. Molecular Aspects of Human Cellular Zinc Homeostasis: Redox Control of Zinc Potentials and Zinc Signals. BioMetals 2009, 22, 149-157.

(3) Vallee, B. L.; Falchuk, K. H. The biochemical basis of zinc physiology. Physiol. Rev. 1993, 73, 79-118.

(4) Lim, N. C.; Freake, H. C.; Brückner, C. Illuminating Zinc in Biological Systems. Chem.-Eur. J. 2005, 11, 38-49.

(5) Frederickson, C. J.; Koh, J.-Y.; Bush, A. I. The Neurobiology of Zinc in Health and Disease. Nat. Rev. Neurosci. 2005, 6, 449-462.

(6) Sladek, R.; Rocheleau, G.; Rung, J.; Dina, C.; Shen, L.; Serre, D.; Boutin, P.; Vincent, D.; Belisle, A.; Hadjadj, S.; et al. A Genome-Wide 
Association Study Identifies Novel Risk Loci for Type 2 Diabetes. Nature 2007, 445, 881-885.

(7) Chimienti, F.; Devergnas, S.; Pattou, F.; Schuit, F.; GarciaCuenca, R.; Vandewalle, B.; Kerr-Conte, J.; Van Lommel, L.; Grunwald, D.; Favier, A.; et al. In vivo expression and functional characterization of the zinc transporter ZnT8 in glucose-induced insulin secretion. J. Cell Sci. 2006, 119, 4199-4206.

(8) Que, E. L.; Domaille, D. W.; Chang, C. J. Metals in Neurobiology: Probing Their Chemistry and Biology with Molecular Imaging. Chem. Rev. 2008, 108, 1517-1549.

(9) Shamsipur, M.; Yousefi, M.; Hosseini, M.; Ganjali, M. R.; Sharghi, H.; Naeimi, H. A Schiff Base Complex of $\mathrm{Zn}(\mathrm{II})$ as a Neutral Carrier for Highly Selective PVC Membrane Sensors for the Sulfate Ion. Anal. Chem. 2001, 73, 2869-2874.

(10) Que, E. L.; Domaille, D. W.; Chang, C. J. Metals in Neurobiology: Probing Their Chemistry and Biology with Molecular Imaging (Published on the Web April 22, 2008.). Chem. Rev. 2008, $108,4328$.

(11) Wong, B. A.; Friedle, S.; Lippard, S. J. Subtle Modification of 2,2-Dipicolylamine Lowers the Affinity and Improves the Turn-On of Zn(II)-Selective Fluorescent Sensors. Inorg. Chem. 2009, 48, 70097011.

(12) Cuajungco, M. P.; Lees, G. J. Zinc Metabolism in the Brain: Relevance to Human Neurodegenerative Disorders. Neurobiol. Dis. 1997, 4, 137-169.

(13) Bush, A. I. The metallobiology of Alzheimer's disease. Trends Neurosci. 2003, 26, 207-214.

(14) Kim, H.; Kang, J.; Kim, K. B.; Song, E. J.; Kim, C. A Highly Selective Quinoline-Based Fluorescent Sensor for $\mathrm{Zn}(\mathrm{II})$. Spectrochim. Acta, Part A 2014, 118, 883-887.

(15) Wu, D.-Y.; Xie, L.-X.; Zhang, C.-L.; Duan, C.-Y.; Zhao, Y.-G.; Guo, Z.-J. Quinoline-Based Molecular Clips for Selective Fluorescent Detection of Zn2+. J. Chem. Soc., Dalton Trans. 2006, 29, 3528-3533.

(16) Liu, H.; Dong, Y.; Zhang, B.; Liu, F.; Tan, C.; Tan, Y.; Jiang, Y. An Efficient Quinoline-Based Fluorescence Sensor for Zinc(II) and Its Application in Live-Cell Imaging. Sens. Actuators, B 2016, 234, 616-624.

(17) Mikata, Y.; Sato, Y.; Takeuchi, S.; Kuroda, Y.; Konno, H.; Iwatsuki, S. Quinoline-Based Fluorescent Zinc Sensors with Enhanced Fluorescence Intensity, $\mathrm{Zn} / \mathrm{Cd}$ Selectivity and Metal Binding Affinity by Conformational Restriction. Dalton Trans. 2013, 42, 9688-9698.

(18) Zhang, Z.; Shi, Y.; Pan, Y.; Cheng, X.; Zhang, L.; Chen, J.; Li, M.-J.; Yi, C. Quinoline Derivative-Functionalized Carbon Dots as a Fluorescent Nanosensor for Sensing and Intracellular Imaging of Zn2+. J. Mater. Chem. B 2014, 2, 5020-5027.

(19) Nolan, E. M.; Jaworski, J.; Okamoto, K.-I.; Hayashi, Y.; Sheng, M.; Lippard, S. J. QZ1 and QZ2: Rapid, Reversible QuinolineDerivatized Fluoresceins for Sensing Biological Zn(II). J. Am. Chem. Soc. 2005, 127, 16812-16823.

(20) Wang, P.; Zhou, D.; Chen, B. High Selective and Sensitive Detection of $\mathrm{Zn}$ (II) Using Tetrapeptide-Based Dansyl Fluorescent Chemosensor and Its Application in Cell Imaging. Spectrochim. Acta, Part A 2018, 204, 735-742.

(21) Wang, P.; Wu, J.; An, Y.; Liao, Y. A Novel Fluorescent Chemosensor for Detection of $\mathrm{Zn}$ (II)Ions Based on DansylAppended Dipeptide in Two Different Living Cells. Spectrochim. Acta, Part A 2019, 220, 117140.

(22) Parola, A. J.; Lima, J. C.; Pina, F.; Pina, J.; de Melo, J. S.; Soriano, C.; García-España, E.; Aucejo, R.; Alarcón, J. Synthesis and Photophysical Properties of Dansyl-Based Polyamine Ligands and Their Zn(II) Complexes. Inorg. Chim. Acta 2007, 360, 1200-1208.

(23) An, J.-m.; Yan, M.-h.; Yang, Z.-y.; Li, T.-r.; Zhou, Q.-x. A Turnon Fluorescent Sensor for $\mathrm{Zn}$ (II) Based on Fluorescein-Coumarin Conjugate. Dyes Pigm. 2013, 99, 1-5.

(24) Ma, J.; Sheng, R.; Wu, J.; Liu, W.; Zhang, H. A New CoumarinDerived Fluorescent Sensor with Red-Emission for $\mathrm{Zn} 2+$ in Aqueous Solution. Sens. Actuators, B 2014, 197, 364-369.

(25) Lim, N. C.; Schuster, J. V.; Porto, M. C.; Tanudra, M. A.; Yao, L.; Freake, H. C.; Brückner, C. Coumarin-Based Chemosensors for
Zinc(II): Toward the Determination of the Design Algorithm for CHEF-Type and Ratiometric Probes. Inorg. Chem. 2005, 44, 20182030.

(26) Aulsebrook, M. L.; Graham, B.; Grace, M. R.; Tuck, K. L. Coumarin-Based Fluorescent Sensors for Zinc(II) and Hypochlorite. Supramol. Chem. 2015, 27, 798-806.

(27) Qin, J.-c.; Fan, L.; Yang, Z.-y. A Small-Molecule and Resumable Two-Photon Fluorescent Probe for $\mathrm{Zn} 2+$ Based on a Coumarin Schiff-Base. Sens. Actuators, B 2016, 228, 156-161.

(28) Burdette, S. C.; Walkup, G. K.; Spingler, B.; Tsien, R. Y.; Lippard, S. J. Fluorescent Sensors for $\mathrm{Zn} 2+$ Based on a Fluorescein Platform: Synthesis, Properties and Intracellular Distribution. J. Am. Chem. Soc. 2001, 123, 7831-7841.

(29) Du, F.; Wang, H.; Bao, Y.; Liu, B.; Zheng, H.; Bai, R. Conjugated Coordination Polymers Based on 8-Hydroxyquinoline Ligands: Impact of Polyhedral Oligomeric Silsesquioxanes on Solubility and Luminescence. J. Mater. Chem. 2011, 21, 1085910864.

(30) Costela, A.; Garcia-Moreno, I.; Cerdan, L.; Martin, V.; Garcia, O.; Sastre, R. Dye-Doped POSS Solutions: Random Nanomaterials for Laser Emission. Adv. Mater. 2009, 21, 4163-4166.

(31) Liras, M.; Pintado-Sierra, M.; Amat-Guerri, F.; Sastre, R. New BODIPY Chromophores Bound to Polyhedral Oligomeric Silsesquioxanes (POSS) with Improved Thermo- and Photostability. J. Mater. Chem. 2011, 21, 12803-12811.

(32) Pu, K.-Y.; Li, K.; Liu, B. Cationic Oligofluorene-Substituted Polyhedral Oligomeric Silsesquioxane as Light-Harvesting Unimolecular Nanoparticle for Fluorescence Amplification in Cellular Imaging. Adv. Mater. 2010, 22, 643-646.

(33) Dudziec, B.; Żak, P.; Marciniec, B. Synthetic Routes to Silsesquioxane-Based Systems as Photoactive Materials and Their Precursors. Polymers 2019, 11, 504.

(34) Liu, H.; Liu, H. Selective Dye Adsorption and Metal Ion Detection Using Multifunctional Silsesquioxane-Based Tetraphenylethene-Linked Nanoporous Polymers. J. Mater. Chem. A 2017, 5, 9156-9162.

(35) Cinà, V.; Carbonell, E.; Fusaro, L.; García, H.; Gruttadauria, M.; Giacalone, F.; Aprile, C. Tuneable Emission of Polyhedral Oligomeric Silsesquioxane Based Nanostructures that Self-Assemble in the Presence of Europium(III) Ions: Reversible trans-to-cis Isomerization. ChemPlusChem 2020, 85, 391-398.

(36) Kunthom, R.; Piyanuch, P.; Wanichacheva, N.; Ervithayasuporn, V. Cage-like Silsesequioxanes Bearing Rhodamines as Fluorescence Hg2+ Sensors. J. Photochem. Photobiol., A 2018, 356, $248-255$.

(37) Zhou, H.; Ye, Q.; Wu, X.; Song, J.; Cho, C. M.; Zong, Y.; Tang, B. Z.; Hor, T. S. A.; Yeow, E. K. L.; Xu, J. A Thermally Stable and Reversible Microporous Hydrogen-Bonded Organic Framework: Aggregation Induced Emission and Metal Ion-Sensing Properties. J. Mater. Chem. C 2015, 3, 11874-11880.

(38) Omer, N.; Zhang, F.; Zhao, G.; Guang, S.; Xu, H. Highly Selective Chemosensor for Repetitive Detection of Fe3+ in Pure Water and Bioimaging. Analyst 2019, 144, 3414-3421.

(39) Xu, Q.; Li, Z.; Li, H. Water-Soluble Luminescent Hybrid Composites Consisting of Oligosilsesquioxanes and Lanthanide Complexes and Their Sensing Ability for Cu2+. Chem.-Eur. J. 2016, 22, 3037-3043.

(40) Chanmungkalakul, S.; Ervithayasuporn, V.; Boonkitti, P.; Phuekphong, A.; Prigyai, N.; Kladsomboon, S.; Kiatkamjornwong, S. Anion Identification Using Silsesquioxane Cages. Chem. Sci. 2018, 9, 7753-7765.

(41) Chanmungkalakul, S.; Ervithayasuporn, V.; Hanprasit, S.; Masik, M.; Prigyai, N.; Kiatkamjornwong, S. Silsesquioxane Cages as Fluoride Sensors. Chem. Commun. 2017, 53, 12108-12111.

(42) Liu, J.; Liu, Y.; Jiang, X.; Luo, Y.; Lyu, Y. POSS-Based Microporous Polymers: Efficient Friedel-Crafts Synthesis, CO2 capture and Separation Properties. Microporous Mesoporous Mater. 2017, 250, 203-209. 
(43) Mohamed, M. G.; Liu, N.-Y.; EL-Mahdy, A. F. M.; Kuo, S.-W. Ultrastable Luminescent Hybrid Microporous Polymers Based on Polyhedral Oligomeric Silsesquioxane for CO2 Uptake and Metal Ion Sensing. Microporous Mesoporous Mater. 2021, 311, 110695.

(44) Xiang, K.; Li, Y.; Xu, C.; Li, S. POSS-Based Organic-Inorganic Hybrid Nanomaterials: Aggregation-Enhanced Emission, and Highly Sensitive and Selective Detection of Nitroaromatic Explosives in Aqueous Media. J. Mater. Chem. C 2016, 4, 5578-5583.

(45) ÇeliK Küçük, A.; Matsui, J.; Miyashita, T. Synthesis of MetalloSupramolecular Materials Based on Terpyridine Functionalized Double-Decker Silsesquioxane with Improved Complexation Efficiency. Turk. J. Chem. 2020, 44, 296-308.

(46) Au-Yeung, H.-L.; Tam, A. Y.-Y.; Leung, S. Y.-L.; Yam, V. W.-W. Supramolecular Assembly of Platinum-Containing Polyhedral Oligomeric Silsesquioxanes: An Interplay of Intermolecular Interactions and a Correlation between Structural Modifications and Morphological Transformations. Chem. Sci. 2017, 8, 2267-2276.

(47) Carbonell, E.; Bivona, L. A.; Fusaro, L.; Aprile, C. Silsesquioxane-Terpyridine Nano Building Blocks for the Design of Three-Dimensional Polymeric Networks. Inorg. Chem. 2017, 56, 6393-6403.

(48) Yang, X.; Liu, H. Ferrocene-Functionalized SilsesquioxaneBased Porous Polymer for Efficient Removal of Dyes and Heavy Metal Ions. Chem.-Eur. J. 2018, 24, 13504-13511.

(49) Au-Yeung, H.-L.; Leung, S. Y.-L.; Tam, A. Y.-Y.; Yam, V. W.-W. Transformable Nanostructures of Platinum-Containing Organosilane Hybrids: Non-covalent Self-Assembly of Polyhedral Oligomeric Silsesquioxanes Assisted by $\mathrm{Pt} \cdots \mathrm{Pt}$ and $\pi-\pi$ Stacking Interactions of Alkynylplatinum(II) Terpyridine Moieties. J. Am. Chem. Soc. 2014, 136, 17910-17913.

(50) Boča, M.; Jameson, R. F.; Linert, W. Fascinating Variability in the Chemistry and Properties of 2,6-Bis-(Benzimidazol-2-Yl)-Pyridine and 2,6-Bis-(Benzthiazol-2-Yl)-Pyridine and Their Complexes. Coord. Chem. Rev. 2011, 255, 290-317.

(51) Wu, H.-L.; Yuan, J.-K.; Huang, X.-C.; Kou, F.; Liu, B.; Jia, F.; Wang, K.-T.; Bai, Y. Two Zinc(II) and Cadmium(II) Complexes Based on the V-Shaped Ligand 2,6-Bis(2-Benzimidazolyl)Pyridine: Synthesis, Crystal Structure, DNA-Binding Properties and Antioxidant Activities. Inorg. Chim. Acta 2012, 390, 12-21.

(52) Wu, H.; Huang, X.; Yuan, J.; Kou, F.; Jia, F.; Liu, B.; Wang, K. A V-Shaped Ligand 2,6-Bis(2-Benzimidazolyl)Pyridine and Its Picrate Mn(II) Complex: Synthesis, Crystal Structure and DNA-Binding Properties. Eur. J. Med. Chem. 2010, 45, 5324-5330.

(53) Rajnák, C.; Titiš, J.; Fuhr, O.; Ruben, M.; Boča, R. Low Spin $\mathrm{Fe}$ (II) Complexes Formed of Monosubstitued 2,6-Bis(2Benzimidazolyl)Pyridine Ligands. Polyhedron 2017, 123, 122-131.

(54) Badiei, A.; Razavi, B. V.; Goldooz, H.; Mohammadi Ziarani, G.; Faridbod, F.; Ganjali, M. R. A Novel Fluorescent Chemosensor Assembled with 2,6-Bis(2-Benzimidazolyl)Pyridine-Functionalized Nanoporous Silica-Type SBA-15 for Recognition of $\mathrm{Hg} 2+$ Ion in Aqueous Media. Int. J. Environ. Res. 2018, 12, 109-115.

(55) Vosough Razavi, B.; Badiei, A.; Lashgari, N.; Mohammadi Ziarani, G. 2,6-Bis(2-Benzimidazolyl)Pyridine Fluorescent RedShifted Sensor for Recognition of Zinc(II) and a Calorimetric Sensor for Iron Ions. J. Fluoresc. 2016, 26, 1723-1728.

(56) Liu, S.-G.; Zuo, J.-L.; Li, Y.-Z.; You, X.-Z. Syntheses, Crystal Structures of Blue Luminescent Complexes Based on 2,6-Bis(Benzimidazolyl) Pyridine. J. Mol. Struct. 2004, 705, 153-157.

(57) Mashraqui, S. H.; Chandiramani, M.; Ghorpade, S.; Upathayay, J.; Mestri, R.; Chilekar, A. A Simple 2,6-Bis(2-Benzimidazole)Pyridyl Incorporated Optical Probe Affording Selective Ratiometric Targeting of Biologically and Environmentally Significant $\mathrm{Zn} 2+$ under Buffer Condition. J. Inclusion Phenom. Macrocyclic Chem. 2015, 84, 129-135.

(58) Furgal, J. C.; Goodson, T., III; Laine, R. M. D ${ }_{5 \mathrm{~h}}\left[\mathrm{PhSiO}_{1.5}\right]_{10}$ Synthesis via $\mathrm{F}^{-}$Catalyzed Rearrangement of $\left[\mathrm{PhSiO}_{1.5}\right]_{\mathrm{n}}$. An Experimental/Computational Analysis of Likely Reaction Pathways. Dalton Trans. 2016, 45, 1025-1039.

(59) Abdolmaleki, A.; Molavian, M. R. Synthesis and Characterization of Co Nanocomposite Based on Poly(Benzimidazole-Amide)
Matrix and Their Behavior as Catalyst in Oxidation Reaction. Polym.Plast. Technol. Eng. 2015, 54, 1241-1250.

(60) Furgal, J. C.; Jung, J. H.; Clark, S.; Goodson, T.; Laine, R. M. Beads on a Chain (BoC) Phenylsilsesquioxane (SQ) Polymers via FCatalyzed Rearrangements and ADMET or Reverse Heck CrossCoupling Reactions: Through Chain, Extended Conjugation in 3-D with Potential for Dendronization. Macromolecules 2013, 46, 75917604.

(61) Asuncion, M. Z.; Laine, R. M. Fluoride Rearrangement Reactions of Polyphenyl- and Polyvinylsilsesquioxanes as a Facile Route to Mixed Functional Phenyl, Vinyl T10 and T12 Silsesquioxanes. J. Am. Chem. Soc. 2010, 132, 3723-3736.

(62) Orndorff, W. R.; Gibbs, R. C.; McNulty, S. A.; Shapiro, C. V. The Absorption Spectra of Benzene and Toluene in Alcoholic Solution. The Spectroscopic Detection of Benzene as an Impurity in Organic Compounds. J. Am. Chem. Soc. 1928, 50, 831-837.

(63) Mazumdar, P.; Maity, S.; Shyamal, M.; Das, D.; Sahoo, G. P.; Misra, A. Proton Triggered Emission and Selective Sensing of Picric Acid by the Fluorescent Aggregates of 6,7-Dimethyl-2,3-Bis-(2Pyridyl)-Quinoxaline. Phys. Chem. Chem. Phys. 2016, 18, 7055-7067.

(64) Sucre-Rosales, E.; Fernández-Terán, R.; Urdaneta, N.; Hernández, F. E.; Echevarria, L. Solvatochromism and Intramolecular Charge Transfer in Dialkylamino-Substituted Halogenated Thienyl Chalcone Analogues. Chem. Phys. 2020, 537, 110854.

(65) Furgal, J. C.; Jung, J. H.; Goodson, T.; Laine, R. M. Analyzing Structure-Photophysical Property Relationships for Isolated T8, T10, and T12 Stilbenevinylsilsesquioxanes. J. Am. Chem. Soc. 2013, 135, 12259-12269.

(66) Hwan Jung, J.; Furgal, J. C.; Goodson, T.; Mizumo, T.; Schwartz, M.; Chou, K.; Vonet, J.-F.; Laine, R. M. 3-D Molecular Mixtures of Catalytically Functionalized [VinylSiO 1.5] 10/[VinylSiO 1.5] 12. Photophysical Characterization of Second Generation Derivatives. Chem. Mater. 2012, 24, 1883-1895.

(67) Sahana, A.; Banerjee, A.; Lohar, S.; Panja, S.; Mukhopadhyay, S. K.; Sanmartín Matalobos, J.; Das, D. Fluorescence Sensing of Arsenate at Nanomolar Level in a Greener Way: Naphthalene Based Probe for Living Cell Imaging. Chem. Commun. 2013, 49, $7231-7233$

(68) Yu, X.-Y.; Deng, L.; Zheng, B.; Zeng, B.-R.; Yi, P.; Xu, X. A Spectroscopic Study on the Coordination and Solution Structures of the Interaction Systems between Biperoxidovanadate Complexes and the Pyrazolylpyridine-like Ligands. Dalton Trans. 2014, 43, 15241533. 